\title{
PERBEDAAN INFORMASI CITRA DIAGNOSTIK ANTARA SEKUEN T2 TSE STIR DAN T2 TSE DIXON PADA PEMERIKSAAN MRI LUMBAL POTONGAN SAGITAL DENGAN KASUS RADICULOPATHY
}

\author{
${ }^{1}$ Fisnandya Meita Astari, ${ }^{2}$ Rasyid, ${ }^{3}$ Fatimah \\ ${ }^{1}$ Universitas 'Aisyiyah Yogyakarta \\ ${ }^{2,3}$ Poltekkes Kemenkes Semarang \\ e-mail: fisnandyameitaa@gmail.com
}

\begin{abstract}
Backgroud: T2 Weighted Image Turbo Spin Echo Short Tau Inversion Recovery (T2 TSE STIR) is a sequence to get the image pathologic which can reveal of tissue along surrounding pathology with fat suppresion technique. T2 Weighted Image Turbo Spin Echo Dixon is a sequence to get the image pathologic whic can reveal of tissue along surrounding pathology with fat and water suppresion technique. Based on observations at Dr. Hasan Sadikin Bandung Hospital, in the examination of MRI Lumbal using T2 TSE sequence with Dixon fat suppresion technique, while according to The American College of Radiology (2012), using STIR fat suppresion technique. The purpose of this research was to know the difference of information diagnostic image that is produced between T2 TSE STIR and T2 TSE Dixon sequences on the examination of MRI lumbal sagittal slice with Radiculopathy case.

Methods: This research of type is experiment. The study was conducted with a 1,5 Tesla MRI at Installation Radiology of General Hospital Dr. Hasan Sadikin Bandung. The research took from of the 22 images of MRI lumbal sagittal slice from T2 TSE STIR and T2 TSE Dixon sequences with Radiculopathy cases. Assesment of the image was done by two respondents and Kappa test was conducted. Furthermore, the results of respondents assessment was analyzed by Wilcoxon different test.

Results: The results showed that the research result Ho rejected and Ha accepted which mean there is a differences of information diagnostic image between T2 TSE STIR and T2 TSE Dixon sequences on the examination of MRI lumbal sagittal slices with Radiculopathy case with $\mathrm{p}$ value $=0,001(\mathrm{p}<0,05)$.

Conclusion: T2 Sequence TSE Dixon can produce MRI images with more specific and homogeneous fat suppresion, thus providing more informative diagnostic information than T2 TSE STIR sequences.
\end{abstract}

Keywords : T2 TSE STIR, T2 TSE Dixon, MRI Lumbal, Radiculopathy

\section{Pendahuluan}

Magnetic Resonance Imaging (MRI) merupakan salah satu modalitas imejing diagnostik yang dapat menghasilkan irisan anatomi tubuh secara multiplanar dengan kontras resolusi yang sangat baik. MRI dapat mendeteksi perbedaan kontras pada jaringan lebih baik daripada CT Scan. MRI sangat baik digunakan untuk mendeteksi suatu lesi pada jaringan lunak (Blink, 2004).

Teknik pencitraan MRI relatif komplek karena gambaran yang dihasilkan tergantung pada banyaknya protokol yang digunakan. MRI merupakan metode pilihan untuk diagnosa berbagai jenis penyakit. Beberapa faktor kelebihan yang dimiliki oleh MRI jika ditinjau dari segi pencitraannya adalah kemampuannya dalam membuat potongan coronal, sagital dan aksial serta oblik tanpa mengubah posisi tubuh pasien. Dari segi hasil pencitraan, MRI lebih dapat membedakan dengan jelas antara jaringan, lemak, dan massa (Repository, 2016).

Pemeriksaan untuk MRI secara umum dilaksanakan dengan menggunakan pembobotan T1- Weighted image dan T2-Weighted Image. T1Weighted image digunakan untuk melihat anatomi sedangkan T2-Weighted image digunakan untuk melihat patologi atau kelainan. (Westbrook, 2002). Pemeriksaan MRI dapat dilakukan dalam pemeriksaan MRI Kepala, MRI Ekstremitas baik 
ekstremitas atas maupun ekstremitas bawah, MR Myelografi, MRI Spine seperti Vertebrae Cervical, Thoracal dan Lumbal.

Pemeriksaan MRI Lumbal banyak ditemui di Rumah Sakit dengan berbagai macam kasus, seperti Hernia Nucleus Pulposus (HNP), Radiculopathy, Myeloradiculopathy, dan Spondilitis TB. Berdasarkan data pasien di RSUP Dr. Hasan Sadikin Bandung, selama bulan November-Desember 2016, terdapat 55 pasien MRI Lumbal dengan kasus Radiculopathy merupakan kasus yang paling banyak ditemukan yaitu sebanyak 15 kasus. Kasus lainnya yang ditemukan yaitu myeloradiculopathy, spondilitis TB, Hernia Nucleus Pulposus (HNP), meningiomyeloma, compresion fracture, conus cuda syndrome, multiple myeloma, low back pain, spondilesistesis dan spina bifida.

Radiculopathy adalah rasa nyeri pada distribusi dermatomal, gejala sensorik di sepanjang dermatome yang sama, kekurangan dalam distribusi myotomal yang sesuai dan tidak adanya refleks atau terasa refleks yang tertekan (Brust, 2008).

Radiculopathy dapat terjadi pada semua bagian radiks medula spinalis dan banyak dilaporkan ruptur atau herniasi pada diskus intervertebralis pada segmen cervicalis atau lumbalis, sedang pada radiks thoracalis jarang dilaporkan (J, Iskandar, Dr, 2002).

Penyebab Radiculopathy yang paling sering ditemukan adalah yang berkaitan dengan lesi, termasuk herniated disk, spondylosis, dan lesi massa seperti abses epidural dan tumor metastase dari spine (Preston, D, C, 2002). Sedangkan Radiculopathy pada daerah lumbosacral disebabkan oleh disk herniation atau perubahan spondylitic, terutama pada facet joint atau kalsifikasi ligamentum flavum. Ketika dikombinasikan, perubahan ini akan menghasilkan stenosis pada lumbal canal (Brust, 2008).

Terdapat beberapa teknik dalam mensupresi lemak. Beberapa teknik tersebut diantaranya adalah fat saturation, Short Tau Inversion Recovery (STIR), Spatial Inversion Recovery (SPIR) dan Teknik Dixon. (Westbrook, 2012). Menurut The American College of Radiology (2012), untuk mensupresi sinyal lemak terutama dalam pemeriksaan MRI Lumbal, lebih baik menggunakan teknik STIR (Short Tau Inversion Recovery). Teknik STIR, akan menghasilkan image dengan fat berwarna gelap. Teknik ini didesain untuk menghilangkan sinyal lemak dan menonjolkan cairan serta edema. Pulsa sequence ini paling sensitif untuk menilai perubahan patologis dan edema pada tulang dan jaringan lunak pada spinal. Selain menggunakan STIR, untuk menekan lemak terdapat alternatif teknik lain yang dapat digunakan yaitu teknik Dixon.

Teknik Dixon dapat diterapkan di sekuen gradient echo dan spin echo dengan beberapa teknik menggunakan multirepetition atau multiecho. Secara skematik, akuisisi pertama pada waktu echo ketika proton lemak dan air pada in phase (disebut sinyal in phase [SIP]), sama seperti tipe akuisisi konvensional. Akuisisi kedua pada waktu echo ketika proton lemak dan air pada out of phase (disebut sinyal out of phase [SOP]), Perubahan SIP ke SOP menghasilkan water image dengan supresi sinyal lemak. Dan subtraksi SOP dari SIP menghasilkan fat image dengan supresi sinyal air. Keuntungan teknik dixon yaitu homogeneous dan reliable dalam supresi lemak, menghasilkan SNR yang tinggi jika dibandingkan dengan STIR, dapat diaplikasikan untuk mengevaluasi tumor dan penyakit neuromuscular serta dapat digunakan dalam akuisisi single image dengan atau tanpa fat suppression. Kerugian teknik dixon yaitu memiliki waktu akuisisi data yang lebih lama (Del, Filippo, 2014).

Menurut Chin, Chyntia T. (2014), dalam mengevaluasi Radiculopathy pada MRI lumbal memiliki spesifisitas yang terbatas terhadap perubahan pada sebagian besar pasien ditemukan dengan tanpa gejala. Penggunaan sekuen STIR dalam pemeriksaan MRI, dapat mengakibatkan sinyal abnormal akan meningkat, sehingga dapat membantu mengevaluasi gejala penyakit yaitu Radiculopathy.

Berdasarkan hasil pengamatan penulis di Instalasi Radiologi Rumah Sakit Umum Pusat Dr. Hasan Sadikin Bandung, pemeriksaan MRI Lumbal dengan klinis Radiculopathy menggunakan sekuen T1 TSE sagital, T1 TSE transversal, T2 TSE sagital, T2 TSE transversal, T2 TSE coronal, T2 TSE dixon sagital, T2 HASTE coronal myelo dan T2 HASTE sagital myelo. Penggunaan sekuen T2 TSE STIR Sagital, digantikan dengan penggunaan sekuen T2 TSE Dixon Sagital. Hal ini terdapat perbedaan antara pemeriksaan yang dilaksanakan di lapangan dengan teori menurut The American College of Radiology (2012). Letak perbedaan antara keduanya yaitu teknik yang digunakan untuk menekan lemak dengan teknik STIR. Sedangkan kenyataan di lapangan, teknik utama yang digunakan yaitu teknik Dixon. Serta, meskipun teknik Dixon dapat menghasilkan fat image dan water image dalam waktu yang 
bersamaan, tetapi teknik ini memiliki kekurangan yaitu memiliki waktu akuisisi data yang lebih lama.

\section{Metode}

Jenis penelitian ini adalah penelitian kuantitatif dengan pendekatan eksperimental. Pengambilan data dilakukan pada bulan April sampai Mei 2017 di Instalasi Radiologi RSUP Dr. Hasan Sadikin Bandung. Populasi dan sampel penelitian adalah citra MRI Lumbal sekuen T2 Weighted Turbo Spin Echo (TSE) STIR dan Dixon potongan sagital dengan menggunakan 11 pasien. Prosedur penelitian dengan melakukan pemeriksaan MRI Lumbal dengan rutin yang digunakan, yaitu T2 HASTE coronal myelo, T2 HASTE sagital myeloT1 TSE sagital, T2 TSE sagital, T1 TSE sagital, T2 TSE dixon sagital, T2 TSE coronal, .T2 TSE transversal, dan T1 TSE transversal. Selanjutnya membuat sekuen tambahan yaitu T2 TSE STIR. Citra MRI yang dihasilkan kemudian dilakukan penilaian oleh dua responden (dokter spesialis radiologi). Kriteria yang dinilai yaitu corpus vertebrae, intervertebral disk, ligament, spinal cord, dan stenosis spinal

Analisis data dilakukan uji statistik dengan aplikasi SPPS 17 for windows. Data tersebut diuji dengan Wilcoxon sign rank test untuk menilai ada tidaknya perbedaan yang signifikan pada dua metode fat suppression tersebut dengan test kemaknaan 95\%. Untuk menilai metode yang lebih jelas menggambarkan informasi diagnostik MRI Lumbal dengan patologi Radiculopathy dapat dilihat pada Mean Rank yang tertera pada hasil pengujian Wilcoxon-Signed Rank Test

\section{Hasil dan Pembahasan}

Penelitian dilakukan pada 11 pasien dengan kasus Radiculopathy pada daerah Os. Vertebrae Lumbal, dengan berbagai penyebab Radiculopathy diantaranya. Hernia Nucleus Pulposus dan Spondylesthesis. Masing-masing pasien dilakukan scanning MRI Lumbal potongan sagital dengan sekuen T2 TSE STIR (Short Tau Inversion Recovery) dan sekuen T2 TSE Dixon.

\begin{tabular}{c|lcc}
6 & Ny. I & 36 Tahun & HNP \\
7 & Ny. O & 55 Tahun & Spondylesthesis \\
8 & Ny. Y & 43 Tahun & HNP \\
9 & Ny. S & 37 Tahun & HNP \\
10 & Ny. I & 45 Tahun & HNP \\
11 & Ny. S & 51 Tahun & HNP \\
\hline
\end{tabular}

Tabel 2. Hasil Uji Kappa Responden

\begin{tabular}{c|ccc}
\multicolumn{4}{c}{ Tabel 2. Hasil Uji Kappa Responden } \\
\hline No & Sekuen & $\begin{array}{c}\text { Nilai } \\
\text { Kapp } \\
\text { a }\end{array}$ & Keterangan \\
\hline 1 & T2 TSE STIR & 0,73 & $\begin{array}{c}\text { Kesesuaian Persepsi } \\
\text { Kuat }\end{array}$ \\
\hline 2 & T2 TSE Dixon & 0,77 & $\begin{array}{c}\text { Kesesuaian Persepsi } \\
\text { Kuat }\end{array}$
\end{tabular}

Informasi Citra Diagnostik antara Sekuen T2 TSE STIR dan T2 TSE Dixon pada Pemeriksaan MRI Lumbal Potongan Sagital dengan Kasus Radiculopathy

Data diperoleh dari hasil penilaian citra oleh radiolog 2 dengan cara memberikan nilai skor 1, 2, 3 , dan 4 pada setiap citra yang dihasilkan oleh sekuen T2 TSE STIR dan T2 TSE Dixon. Kemudian nilai skor masing-masing citra dari responden (radiolog 2) tersebut dirangkum dan dianalisis dengan menggunakan SPSS 17 melalui descriptive statistics. Hasil yang didapat sebagai berikut :

Perbandingan Penilaian Visualisasi Corpus Vertebrae antara Sekuen T2 TSE STIR dan T2 TSE Dixon

Tabel 3 Perbandingan Penilaian Visualisasi Corpus Vertebrae antara Sekuen T2 TSE STIR dan T2 TSE Dixon

\begin{tabular}{|c|c|c|c|c|c|}
\hline \multirow{7}{*}{$\begin{array}{c}\text { Corpus } \\
\text { Vertebrae }\end{array}$} & \multirow{3}{*}{$\begin{array}{r}\text { Kriteria } \\
\text { Penilaian }\end{array}$} & \multicolumn{4}{|c|}{ Kelompok Sekuen } \\
\hline & & \multicolumn{2}{|c|}{ T2 TSE STIR } & \multicolumn{2}{|c|}{ T2 TSE Dixon } \\
\hline & & \multicolumn{2}{|c|}{ Frequency\% } & \multicolumn{2}{|c|}{ Frequency (\%) } \\
\hline & $\begin{array}{l}\text { Tidak } \\
\text { Informatif }\end{array}$ & 0 & 0 & 0 & 0 \\
\hline & $\begin{array}{l}\text { nuraus } \\
\text { Informatif }\end{array}$ & 1 & $9,1 \%$ & 0 & 0 \\
\hline & Informatif & 10 & $90,9 \%$ & 1 & $9,1 \%$ \\
\hline & $\begin{array}{l}\text { Sangat } \\
\text { Informatif }\end{array}$ & 0 & 0 & 10 & $90,9 \%$ \\
\hline \multicolumn{2}{|c|}{ Jumlah } & 11 & $100 \%$ & 11 & $100 \%$ \\
\hline
\end{tabular}

Tabel 1. Karakteristik Sampel Penelitian

\begin{tabular}{c|lcc}
\hline No & Nama & Umur & Penyebab \\
\hline 1 & Ny. Y & 70 Tahun & HNP \\
2 & An. R & 3 Tahun & Spondylesthesis \\
3 & Ny. S & 67 Tahun & HNP \\
4 & Tn. D & 45 Tahun & HNP \\
5 & Ny. E & 37 Tahun & HNP
\end{tabular}

Tabel 3 menunjukkan sebanyak 90,9\% menyatakan sekuen T2 TSE STIR informatif dan 
9,1\% kurang informatif sedangkan untuk sekuen T2 TSE Dixon sebanyak 90,9\% menyatakan sekuen T2 TSE Dixon sangat informatif dan 9,1\% Informatif.
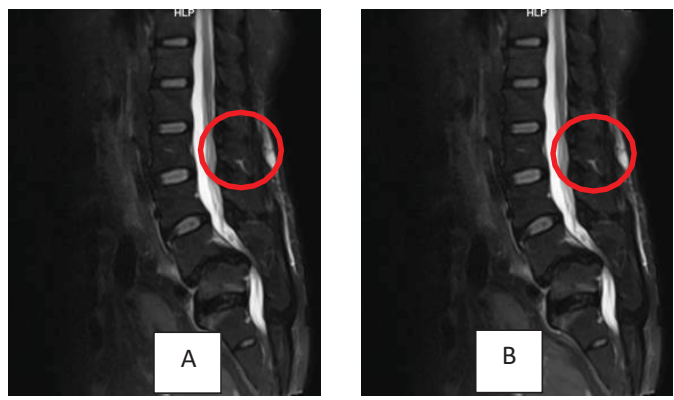

Gambar 1 Radiograf MRI Lumbal visualisasi Corpus Vertebrae Sekuen T2 TSE Dixon (A) dan T2 TSE STIR (B) (RSUP Dr. Hasan Sadikin Bandung, 2017)

b) Perbandingan Penilaian Visualisasi Intervertebral Disk antara Sekuen T2 TSE STIR dan T2 TSE Dixon.

Tabel 4 Perbandingan Penilaian Visualisasi Intervertebral Disk antara Sekuen T2 TSE STIR dan T2 TSE Dixon

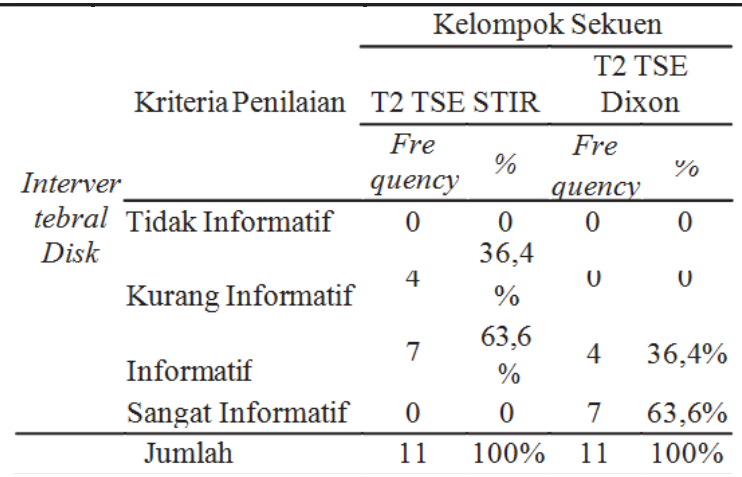

Tabel 4 menunjukkan sebanyak $63,6 \%$ menyatakan sekuen T2 TSE STIR informatif dan 36,4\% kurang informatif sedangkan untuk sekuen T2 TSE Dixon sebanyak 63,6\% menyatakan sekuen T2 TSE Dixon sangat informatif dan sebanyak $36,4 \%$ informatif.

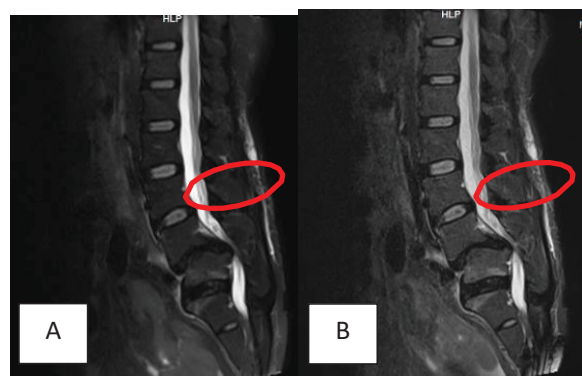

Gambar 2 Radiograf MRI Lumbal visualisasi Intervertebral Disk Sekuen T2 TSE Dixon (A) \& T2 TSE STIR (B) (RSUP Dr. Hasan Sadikin Bandung, 2017) c) Perbandingan Penilaian Visualisasi Ligament antara Sekuen T2 TSE STIR dan T2 TSE Dixon

Tabel 5 Perbandingan Penilaian Visualisasi Ligament antara Sekuen T2 TSE STIR dan T2 TSE Dixon

\begin{tabular}{|c|c|c|c|c|c|}
\hline \multirow{8}{*}{ Ligament } & \multirow{3}{*}{$\begin{array}{l}\text { Kriteria } \\
\text { Penilaian }\end{array}$} & \multicolumn{4}{|c|}{ Kelompok Sekuen } \\
\hline & & \multicolumn{2}{|c|}{$\begin{array}{c}\text { T2 TSE } \\
\text { STIR }\end{array}$} & \multicolumn{2}{|c|}{$\begin{array}{l}\text { T2 TSE } \\
\text { Dixon }\end{array}$} \\
\hline & & $\begin{array}{c}\text { Fre } \\
\text { quency }\end{array}$ & $\%$ & $\begin{array}{c}\text { Fre } \\
\text { quency }\end{array}$ & $\%$ \\
\hline & $\begin{array}{l}\text { Tidak } \\
\text { Informatif }\end{array}$ & 0 & 0 & 0 & 0 \\
\hline & Kurang & & 100 & & \\
\hline & Informatif & 11 & $\%$ & 0 & 0 \\
\hline & Informatif & 0 & $0 \%$ & 11 & $100 \%$ \\
\hline & $\begin{array}{l}\text { Sangat } \\
\text { Intormatıt }\end{array}$ & 0 & 0 & 0 & $0 \%$ \\
\hline \multicolumn{2}{|c|}{ Jumlah } & 11 & $\begin{array}{c}100 \\
\%\end{array}$ & 11 & $100 \%$ \\
\hline
\end{tabular}

Tabel 5 menunjukkan sebanyak 100\% menyatakan sekuen T2 TSE STIR kurang informatif sedangkan untuk sekuen T2 TSE Dixon sebanyak 100\% menyatakan sekuen T2 TSE Dixon informatif.

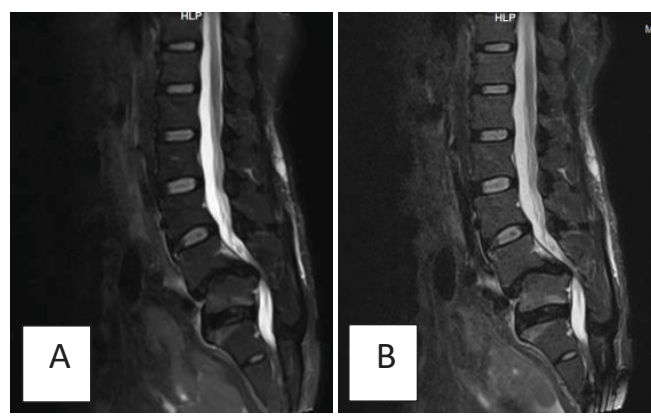

Gambar 3 Radiograf MRI Lumbal visualisasi Ligament Sekuen T2 TSE Dixon (A) dan T2 TSE STIR (B) (RSUP Dr. Hasan Sadikin Bandung, 2017)

d) Perbandingan Penilaian Visualisasi Spinal Cord antara Sekuen T2 TSE STIR dan T2 TSE Dixon

Tabel 6 Perbandingan Penilaian Visualisasi Spinal Cord antara Sekuen T2 TSE STIR dan T2 TSE Dixon

\begin{tabular}{rlcccc}
\hline & & \multicolumn{4}{c}{ Kelompok Sekuen } \\
\cline { 3 - 6 } & $\begin{array}{c}\text { Kriteria } \\
\text { Penilaian }\end{array}$ & \multicolumn{2}{c}{ T2 TSE STIR } & T2 TSE Dixon \\
\cline { 3 - 6 } Spinal & $\begin{array}{c}\text { Fre } \\
\text { quency }\end{array}$ & $\%$ & $\begin{array}{c}\text { Fre } \\
\text { quency }\end{array}$ & $\%$ \\
\cline { 2 - 6 } Cord & $\begin{array}{l}\text { Informatif } \\
\text { Infurang }\end{array}$ & 0 & 0 & 0 & 0 \\
& $\begin{array}{l}\text { Informatif } \\
\text { Informatif }\end{array}$ & 2 & $18,2 \%$ & 0 & 0 \\
& $\begin{array}{l}\text { Sangat } \\
\text { Informatif }\end{array}$ & 0 & $81,8 \%$ & 2 & $18,2 \%$ \\
\hline Jumlah & 11 & $100 \%$ & 9 & $81,8 \%$ \\
\hline
\end{tabular}


Tabel 6 menunjukkan sebanyak 81,8\% menyatakan sekuen T2 TSE STIR informatif dan $18,2 \%$ kurang informatif sedangkan untuk sekuen T2 TSE Dixon sebanyak $81,8 \%$ menyatakan sekuen T2 TSE Dixon sangat informatif dan sebanyak $18,2 \%$ informatif.
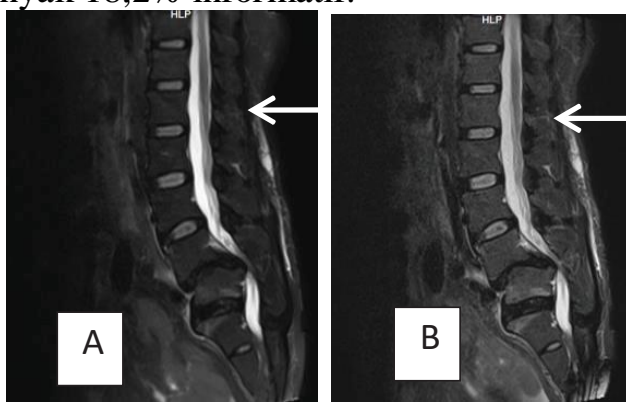

Gambar 4 Radiograf MRI Lumbal visualisasi Spinal Cord Sekuen T2 TSE Dixon (A) dan T2 TSE STIR (B)(RSUP Dr. Hasan Sadikin Bandung, 2017)

Perbandingan Penilaian Visualisasi Stenosis Spinal antara Sekuen T2 TSE STIR dan T2 TSE Dixon

Tabel 7 Perbandingan Penilaian Visualisasi Stenosis Spinal antara Sekuen T2 TSE STIR dan T2 TSE Dixon

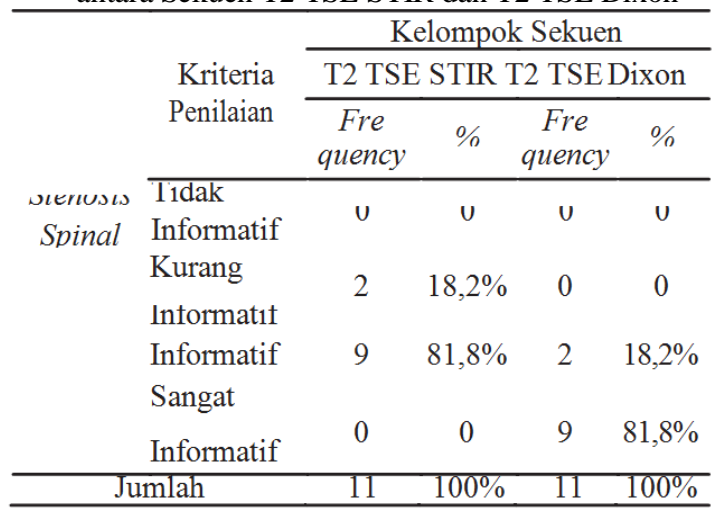

Tabel 7 menunjukkan sebanyak $81,8 \%$ menyatakan sekuen T2 TSE STIR informatif dan $18,2 \%$ kurang informatif sedangkan untuk sekuen T2 TSE Dixon sebanyak $81,8 \%$ menyatakan sekuen T2 TSE Dixon sangat informatif dan sebanyak $18,2 \%$ informatif.
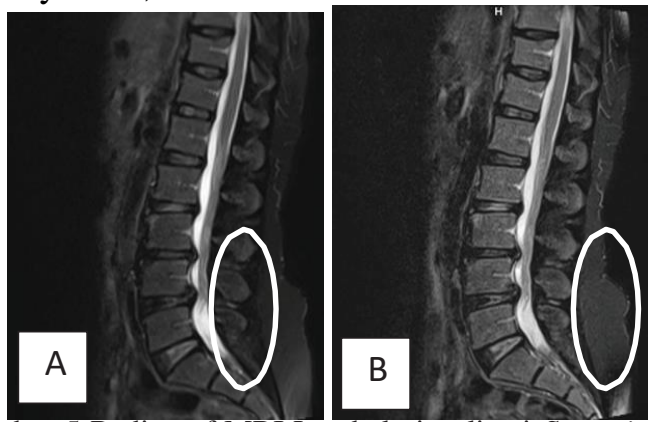

Gambar 5 Radiograf MRI Lumbal visualisasi Stenosis Spinal Sekuen T2 TSE Dixon (A) dan T2 TSE STIR (B) (RSUP Dr. Hasan Sadikin Bandung, 2017)
2. Perbedaan Informasi Citra Diagnostik antara Sekuen T2 TSE STIR dan T2 TSE Dixon pada Pemeriksaan MRI Lumbal Potongan Sagital dengan Kasus Radiculopathy

Tabel 8 Tingkat kemaknaan ( $\mathrm{p}$ value) visualisasi antara sekuen T2 TSE STIR dan T2 TSEDixon.

\begin{tabular}{clc}
\hline No & \multicolumn{1}{c}{ Organ } & Nilai p Value \\
\hline 1 & Corpus Vertebrae & 0,001 \\
2 & Intervertebral Disk & 0,001 \\
3 & Ligament & 0,001 \\
4 & Spinal Cord & 0,001 \\
5 & Stenosis Spinal & 0,001 \\
\hline
\end{tabular}

Hasil uji beda dengan uji statistik wilcoxon antara sekuen T2 TSE STIR dan T2 TSE Dixon pada corpus vertebrae, intervertebral disk, ligament, spinal cord dan stenosis spinal didapatkan nilai $\mathrm{p}$ value $=0,001(\mathrm{p}<0,05)$, sehingga hipotesa nol (Ho) ditolak, berarti ada perbedaan signifikan antara citra sekuen T2 TSE STIR dan T2 TSE Dixon pada tingkat signifikansi $95 \%$.

3. Sekuen yang dapat Menampakkan Informasi Citra Diagnostik Lebih Baik antara T2 TSE STIR dan T2 TSE Dixon pada Pemeriksaan MRI Lumbal Potongan Sagital dengan Kasus Radiculopathy

Tabel 9 Nilai Mean Rank pada Sekuen T2 TSE STIR dan Dixon

\begin{tabular}{ccc}
\multirow{2}{*}{ Organ } & \multicolumn{2}{c}{ Nilai Mean Rank } \\
\cline { 2 - 3 } & T2 TSE STIR & $\begin{array}{c}\mathbf{1} \mathbf{1} \mathbf{~ S E} \\
\text { Dixon }\end{array}$ \\
\hline Corpus Vertebrae & 0,00 & 6,00 \\
Intervertebral & 0,00 & 6,00 \\
Disk & & \\
Ligament & $\mathrm{u}, \mathrm{UU}$ & 0,00 \\
Spinal Cord & 0,00 & 6,00 \\
Stenosis Spinal & 0,00 & 6,00 \\
\hline
\end{tabular}

Uji beda dengan uji statistik wilcoxon antara sekuen T2 TSE STIR dan T2 TSE Dixon pada informasi diagnostik corpus vertebrae, intervertebral disk, ligament, spinal cord dan stenosis spinal didapatkan nilai mean rank untuk sekuen T2 TSE STIR 0,00 dan sekuen T2 TSE Dixon 6,00, dengan demikian pada informasi citra diagnostik antara citra sekuen T2 TSE STIR dan T2 TSE Dixon, T2 TSE Dixon lebih baik dalam menghasilkan informasi citra diagnostik. 
1. Informasi Citra Diagnostik Antara Sekuen T2 TSE STIR dan T2 TSE Dixon pada Pemeriksaan MRI Lumbal Potongan Sagital dengan Kasus Radiculopathy

Informasi citra diagnostik MRI Lumbal Potongan Sagital dengan kasus Radiculopathy yaitu corpus vertebrae, intervertebral disk, ligament (ligamentum longitudinal anterior dan posterior, ligamentum interspinous, ligamentum supraspinous, ligamentum flavum), spinal cord dan stenosis spinal. 5 kriteria penilaian tersebut merupakan kriteria yang dinilai dalam penelitian yang penulis lakukan dan bersifat informatif untuk memberikan informasi citra diagnostik MRI Lumbal potongan sagital pada kasus Radiculopathy. Menurut Brust (2008), stenosis spinal merupakan ciri dari penyakit Radiculopathy, khususnya pada Radiculopathy lumbal. Stenosis spinal atau Bulging ini akan mudah dinilai dalam pemeriksaan MRI dengan teknik fat suppresion.

Gambar 6 menunjukkan stenosis spinal pada citra MRI Lumbal dengan menggunakan teknik fat suppression Dixon serta menunjukkan stenosis spinal pada citra MRI Lumbal dengan tanpa menggunakan teknik fat suppression.

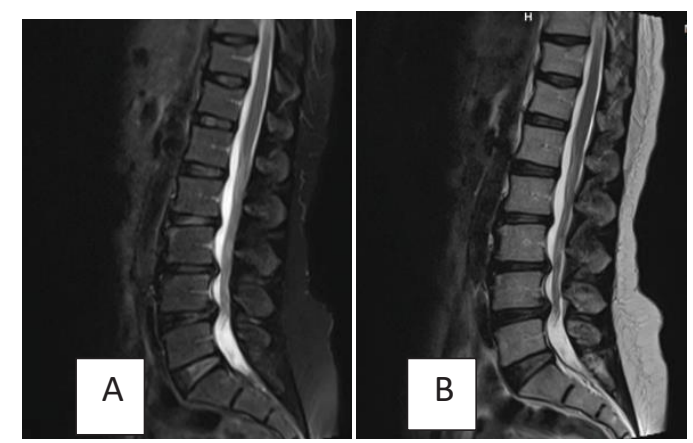

Gambar 6 Radiograf MRI Lumbal visualisasi Stenosis Spinal Teknik Fat Suppression Dixon (A) dan tanpa teknik fat suppression (B) (RSUP Dr. Hasan Sadikin Bandung, 2017)

Sesuai dengan hasil penilaian dokter, citra MRI Lumbal dengan menggunakan teknik fat suppression Dixon akan lebih jelas dan tegas dalam menampakkan stenosis spinal (Brandao, S, 2013). Di dalam Intervertebral Disk terdapat annulus fibrosus dan nucleus pulposus. Komponen keduanya terdiri dari air, collagen dan proteoglycans (PGs), dengan jumlah cairan dan PGs merupakan penyusun terbanyak nucleus pulposus (spineuniverse.com, 2014). Karena komposisi terbanyak berupa air, maka ketika diaplikasikan teknik fat suppresion sinyal lemak akan tersupres sedangkan intensitas sinyal disekitar patologi dan intervertebral disk akan meningkat. Hal ini yang menyebabkan stenosis spinal dapat dinilai dengan baik melalui teknik fat suppresion (Brandao, S, 2013).

Sekuen T2 TSE STIR dan T2 TSE Dixon merupakan sekuen yang menggunakan teknik fat suppresion. Sekuen T2 TSE STIR dan T2 TSE Dixon mampu menekan lemak, namun selain mampu menekan lemak, sekuen T2 TSE Dixon juga mampu menekan cairan. Pada penelitian ini, penulis melakukan penelitian pada pemeriksaan MRI Lumbal potongan sagital dengan kasus Radiculopathy. Dengan kemampuan menekan lemak inilah, stenosis spinal yang merupakan ciri khas dari penyakit Radiculopathy dapat dinilai.

2. Perbedaan Informasi Citra Diagnostik Antara Sekuen T2 TSE STIR dan T2 TSE Dixon pada Pemeriksaan MRI Lumbal Potongan Sagital dengan Kasus Radiculopathy

Berdasarkan hasil uji wilcoxon pada informasi citra diagnostik MRI Lumbal potongan sagital pada kasus Radiculopathy antara sekuen T2 TSE STIR dan T2 TSE Dixon menyatakan bahwa Ho ditolak atau terdapat perbedaan yang signifikan. Ada perbedaan yang signifikan antara sekuen T2 TSE STIR dan T2 TSE Dixon pada organ corpus vertebrae, intervertebral disk, ligament, spinal cord dan stenosis spinal. Masing- masing organ yang dinilai memiliki $\mathrm{p}$ value yaitu ( $p$ value $=0,001$ )

Perbedaan informasi citra diagnostik terjadi karena perbedaan akuisisi data antara sekuen T2 TSE STIR dan T2 TSE Dixon, sehingga menghasilkan kualitas citra yang berbeda. Menurut Westbrook (2002), Short Tau Inversion Recovery (STIR), merupakan teknik suppresi lemak yang menggunakan nilai Time Inversion (TI), dengan nilai TI yang lemah 100-175 ms. Pada saat diaplikasikan pulsa $90^{\circ}$ eksitasi, vector jaringan fat akan berubah arah penyudutan dari $90^{\circ}$ ke $180^{\circ}$ dan mengarah ke full saturasi sehingga sinyal jaringan fat menjadi nol. Namun, fat suppresion ini tidak spesifik, untuk sinyal dari jaringan atau cairan dengan T1 yang sama akan ikut tersupresi (Wu, Jing, 2012). Serta menurut David (2008), sekuen STIR merupakan sekuen yang baik dalam 
menekan lemak akan tetapi memiliki sinyal yang kurang baik. Sedangkan teknik Dixon, merupakan teknik suppresi lemak yang menerapkan dua akuisisi data. Akuisisi pertama pada waktu sinyal lemak dan air dalam keadaan in phase. Akuisisi kedua pada waktu sinyal lemak dan air dalam keadaan out of phase. Selanjutnya untuk mendapatkan fat dan water image didapatkan melalui post processing data secara algorithma. Teknik Dixon ini akan menghasilkan citra dengan fat suppresion yang lebih spesifik, yaitu teknik untuk menekan lemak saja atau menekan cairan dan lemak (Guerini, 2015)

3. Informasi Citra Diagnostik yang Lebih Baik Antara Sekuen T2 TSE STIR dan T2 TSE Dixon pada Pemeriksaan MRI Lumbal Potongan Sagital dengan Kasus Radiculopathy

Berdasarkan hasil uji wilcoxon pada informasi citra diagnostik MRI Lumbal potongan sagital pada kasus Radiculopathy antara sekuen T2 TSE STIR dan T2 TSE Dixon pada organ corpus vertebrae, intervertebral disk, ligament, spinal cord dan stenosis spinal didapatkan hasil mean rank yaitu 6,00 untuk sekuen T2 TSE Dixon dan 0,00 untuk sekuen T2 TSE STIR. Hal ini menunjukkan bahwa sekuen T2 TSE Dixon lebih informatif dalam memberikan informasi citra diagnostik MRI Lumbal potongan sagital pada kasus Radiculopathy.

T2 TSE Dixon, merupakan sekuen yang menggunakan teknik fat suppresed. Dalam penelitian ini, khususnya MRI Lumbal pada kasus Radiculopathy, sekuen tersebut sangat berguna dalam menilai patologi Radiculopathy dengan melihat citra`water image (lemak tersupres). Sekuen T2 TSE Dixon lebih baik dalam mensupres lemak jika dibandingkan dengan sekuen T2 TSE STIR. Karena, menurut Guerini (2015), Teknik Dixon melalui dua akuisisi data, akan menghasilkan citra dengan fat suppresion yang lebih spesifik, yaitu teknik untuk menekan lemak saja atau menekan cairan dan lemak.

Selain dapat menghasilkan fat dan water image sekaligus, Teknik Dixon juga memiliki kelebihan yaitu dapat menghasilkan kualitas citra yang lebih baik yaitu dengan SNR yang tinggi dan supresi lemak yang homogen (Jing Wu, 2012). Kelebihan lain yang dimiliki oleh teknik Dixon adalah tidak sensitif terhadap $\mathrm{B}_{1}$ inhomogeneity (Brandao, S, 2013). Dari kelebihan tersebut, supresi lemak maupun air akan lebih homogen. Pengaruh dari $\mathrm{B}_{1}$ inhomogeneity adalah homogenitas suppresi. Ketika diberi RF pulse, active nuclei akan menjauhi Bo sesuai besar flip angle dan mengalami transversal magnetization. Jika bersifat sensitif terhadap $\mathrm{B}_{1}$ inhomogeneity akan mengubah besar flip angle yang berpengaruh terhadap proses akuisisi data. Teknik Dixon tidak sensitif terhadap $B_{1}$ inhomogeneity, maka hal tersebut tidak akan mempengaruhi proses akuisisi data serta menyebabkan Dixon lebih homogen dalam mensupresi lemak dibandingkan dengan STIR. Dengan supresi lemak yang homogen, dapat menampakkan kontras antara jaringan normal dan patologi yang lebih baik, sehingga dapat meningkatkan clinical acceptance dalam menentukan diagnosa penyakit

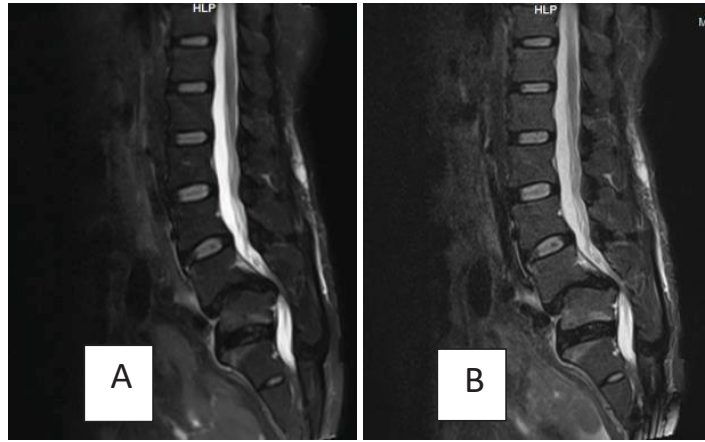

Gambar 7 Radiograf MRI Lumbal mengggunakan Sekuen T2 TSE Dixon (A) dan T2 TSE STIR (B) (RSUP Dr. Hasan Sadikin Bandung, 2017)

Gambar 7 menunjukkan bahwa citra MRI Lumbal dengan menggunakan Sekuen T2 TSE Dixon menghasilkan citra yang lebih baik dibandingkan dengan sekuen T2 TSE STIR, sesuai dengan penilaian radiolog. Citra yang dihasilkan memiliki nilai kontras yang baik, dan detail tiap organ dapat teridentifikasi.

\section{Simpulan}

Informasi citra diagnostik antara sekuen T2 TSE STIR dan T2 TSE Dixon pada pemeriksaan MRI Lumbal potongan sagital dengan kasus Radiculopathy yakni corpus vertebrae, intervertebral disk, ligament (ligamentum longitudinal anterior dan posterior, ligamentum interspinous, ligamentum supraspinous, dan ligamentum flavum), spinal cord dan stenosis 
spinal.

Ada perbedaan secara keseluruhan yang signifikan untuk informasi citra diagnostik corpus vertebrae, intervertebral disk, ligament (ligamentum longitudinal anterior dan posterior, ligamentum interspinous, ligamentum supraspinous, dan ligamentum flavum), spinal cord dan stenosis spinal antara sekuen T2 TSE STIR dan T2 TSE Dixon pada pemeriksaan MRI Lumbal potongan sagital dengan kasus Radiculopathy dengan nilai $\mathrm{p}$ value 0,001 ( $\mathrm{p}<$ $0,05)$, pada tingkat signifikansi $95 \%$.

Sekuen T2 TSE Dixon lebih informatif dibandingkan dengan sekuen T2 TSE STIR pada informasi citra diagnostik MRI Lumbal potongan sagital dengan kasus Radiculopathy antara lain corpus vertebrae, intervertebral disk, ligament (ligamentum longitudinal anterior dan posterior, ligamentum interspinous, ligamentum supraspinous, dan ligamentum flavum), spinal cord dan stenosis spinal, dilihat dari nilai mean rank yaitu 6,00 untuk citra T2 TSE Dixon dan 0,00 untuk citra T2 TSE STIR.

\section{Daftar Pustaka}

Blink, Evert. J, 2004, Basic MRI Physics, Application Specialis MRI

Brandao, S., dkk, 201, Comparing T1 Weighted and T2 Weighted Three Point Dixon Technique with Conventional TI Weighted Fat Saturation and Short Tau Inversion Recovery (STIR) Techniques for The Study of the Lumbar Spine in a Short Bore MRI Machine, Clinical Radiology : Portugal.

Brust, J, C, M, MD, 2006, Current Doagnosis \& Treatment in Neurology, McGraw-Hill : New York

Bushong, Steward C., 2003, Magnetic Resonance Imaging, Physical and Biological Principles, Second edition, Mosby : Washington DC

Chin, Chyntia, T, 2012, Magnetic Resonance Neurography : Brachial Plexus, University of California : California

Dr. Iskandar J, 2002, Radiculopathy, Jakarta

Del, Fillippo, dkk. 2014. Fat Suppression techniques for 3T MR Imaging of the Musculoskeletal System. RSNA : Switzerland

Ginsberg, LIonel, 2005, Lecture Notes Neurology, Erlangga : Jakarta
Hackey, DB. Dkk, 2012. ACR-ASNR-SCBT-MR Practice Paramter for the performance of Magnetic Resonance Imaging (MRI) of the Adult Spine, ACR : United States.

Haldeman, Scot D., Wilis dan Bernard, 2002, An atlas of Back Pain, The parthenon Publishing Group: New York

Guerini, Henri, MD, 2015, Fat Suppression with Dixon Techniques in Musculoskeletal Magnetic Resonance Imaging : A pictorial Review. Thieme Medical : USA

Madden, Michael, E., 2013,Introduction to Sectional Anatomy, Lippincott Williams \& Wilkins : China

Moeller, Torsten B., dan Reif, Emil, M.D., 2003, MRI Parameters and Positioning. Thieme Stuttgart: New York

Moeller, Torsten B., dan Reif, Emil, M.D., 2000, Normal Finding in CT and MRI, Thieme Stuttgart : New York

Nezafat, Maryam, dkk. 2016. Coronary MR Angiography at 3T: Fat Suppression Versus Water-Fat Separation. Cross Mark : London

Preston, David, C, dkk, 2013, Electromyography and Neuromuscular Disorder, Elseiver : China epository, 2016, Radiculopathy Thoracalis, repositori.usu.ac.id

Ribeiro, M. Margarida, 2013, STIR, SPIR and SPAIR Technique in Magnetic Resonance of the Breast : A Comparative Study. Biomedical Science and Engineering : Portugal

Ryan, Stephanie, dkk, 2002, Anatomy fir Diagnostic Imaging Third Edition, Elseiver : United Kingdom

Setiawan, Nugraha, 2007, Penentuan Ukuran Sampel Memakai Rumus Slovin dan Tabel KrejcieMorgan : Telaah Konsep dan Aplikasinya. Universitas Padjajaran : Bandung

Wibowo, Daniel, S. dan Paryana, Widjaya, 2009, Anatomi Tubuh Manusia. Graha Ilmu : Yogyakarta

Westbrook, Catherine, dkk, 1998, MRI In Practice Second Edition, Blackwell Publishing Ltd : UK

Westbrook, Catherine, dkk, 2011, MRI In Practice Fourth Edition, Blackwell Publishing Ltd : UK 
JURNAL RADIOGRAFER INDONESIA, ISSN 2620-9950

Woodward, Peggy, B, S, R, T, (R), (MR), MRI for Technologist, McGraw-Hill : Colombia

Wu, Jing, dkk, 2012, The Application of Fat Suppresion MR Pulse Sequence in the Diagnosis of Bone Joint Di sease, Nanjing Medical University : China 